Огляди літератури, оригінальні дослідження, погляд на проблему, випадок з практики, короткі повідомлення УДК 616.147.17-007.64-089.87-06:616.8-009.62:622.397

DOI 10.11603/1811-2471.2020.v.i1.11073

\title{
ІННОВАЦІЙНІ МЕТОДИ ТЕЛЕМЕДИЧНОГО МОНІТОРИНГУ БОЛЬОВОГО СИНДРОМУ ПІСЛЯ ГЕМОРОїДЕКТОМІї
}

\author{
○І. Я. Дзюбановський, А. І. Цвях, А. Я. Господарський, Р. С. Древніцький \\ Тернопільський національний медичний університет імені І. Я. Горбачевського МОЗ України
}

РЕзЮМЕ. Проведено порівняння методик гемороїдектомії за Мілліганом-Морганом та степлерної гемороїдектомії при хірургічному лікуванні геморою III-IV стадій.

Матеріал і методи. 184 пацієнти, що перенесли гемороїдектомію за Мілліганом-Морганом, та 312 пацієнтів після степлерної гемороїдектомії склали контрольну та основну групи. Було проведено аналіз післяопераційного больового синдрому за допомогою спеціалізованої програми “Ternotel-Vida”, розробленої авторами.

Результати. Рівень болю за візуальною аналоговою шкалою Вонга-Бейкера в післяопераційному періоді на 1-у добу в контрольній групі був значно вищий і склав, у середньому, 8 балів, порівняно з 5 балами у основній групі. На 15-ту добу пацієнти основної групи не відчували болю в післяопераційній ділянці. У пацієнтів контрольної групи больові відчуття зберігалися після двох тижнів. Усі пацієнти з обох груп відмічали, що використання програми в домашніх умовах давало їм відчуття контакту з хірургом та постійного контролю болю зі сторони лікуючого лікаря.

Висновки. Степлерна гемороїдектомія $€$ надійною альтернативою гемороїдектомії за Мілліганом-Морганом і дозволяє зменшити рівень болю в післяопераційному періоді та скоротити період непрацездатності пацієнтів. Використання спеціалізованої комп'ютерної програми дозволяє ліквідувати емоційну складову та реальніше оцінити рівень болю у післяопераційному періоді.

КлючовІ СловА: телемедицина; гемороїдектомія; оцінка болю.

Вступ. За даними ряду авторів [1, 2], захворюваність на геморой становить 130-150 на 1000 осіб дорослого населення, а питома вага цієї патології в структурі колопроктологічних захворювань коливається від 30 до 40 \%. У Європі питома вага гемороїдальної хвороби становить 39-64 \%. Лише у США геморой мають понад 10 млн осіб, тобто понад $4 \%$ населення. Третина з них звертається за медичною допомогою, що становить до 1,5 млн відвідувань щороку. Оперативне лікування гемороїдальної хвороби все ще залишається травматичною процедурою, яка призводить до тривалої втрати працездатності через виражений больовий синдром [3, 4]. Біль - це відчуття, що виникає при дії на організм пошкоджувальних чинників. Існують специфічні больові рецептори, що сприймають дію пошкоджувального агента, у відповідь на яку й виникає відчуття болю. Ці рецептори розташовані в шкірі, м'язах, у суглобах, окісті, підшкірній клітковині та у внутрішніх органах і являють собою вільні нервові закінчення, розгалуження дендриту аферентного нейрона, що несе імпульси в спинний (або довгастий - від рецепторів голови) мозок. У сприйнятті болю беруть участь таламус, гіпоталамус, ретикулярна формація, лімбічна система, потилична та лобна ділянки кори головного мозку $[5,6]$. Але остаточне сприйняття пацієнтом болю виникає за участю нейронів лобної ділянки кори. Завдяки цим нейронам навіть надмірний потік больових імпульсів може сприйматися як слабкий подразник, і навпаки [7]. Завдяки цій інформації больова імпульсація набуває емоційного забарв- лення - у відповідь на біль нерідко виникає почуття страху та інші емоції. Навіть інтонація лікаря, який розпитує пацієнта, може впливати на оцінку вираженості больового синдрому [8].

На думку провідних світових організацій, відкрита гемороїдектомія за Мілліганом-Морганом доволі травматична операція, яка тяжко переноситься пацієнтами. У післяопераційному періоді відзначається виражений больовий синдром, який пов'язаний із масивним пошкодженням анодерми; тривалість госпіталізації та період непрацездатності досить тривалі і можуть займати до 2 місяців. Крім того, гемороїдектомія може супроводжуватися такими серйозними ускладненнями як стриктура анального каналу, недостатність анального сфінктера і формування ран, які довго не загоюються. На сьогодні доброю альтернативою $\epsilon$ виконання гемороїдектомії за допомогою циркулярних степлерів, що відзначається легшим післяопераційним періодом та менш вираженим больовим синдромом.

Мета дослідження - за допомогою спеціалізованої комп'ютерної програми порівняти больовий синдром у післяопераційному періоді після застосування різних методик гемороїдектомії при хірургічному лікуванні геморою III-IV стадій.

Матеріал і методи дослідження. Проаналізовані результати оперативних втручань, проведених 496 пацієнтам з приводу III-IV ст. гемороїдальної хвороби, за період 2014-2019 рр. Усі 496 пацієнтів погодилися надавати оцінку своїх больових відчуттів за допомогою розробленої нами спеціалізованої комп'ютерної програми “Ternotel-Vida”. 
Огляди літератури, оригінальні дослідження, погляд на проблему, випадок з практики, короткі повідомлення Усім хворим виконували клініко-лабораторні обстеження згідно зі стандартами, а також проводили огляд періанальної ділянки, пальцеве дослідження прямої кишки, ректороманоскопію або колоноскопію пацієнтам, старшим 40 років.

Основну групу склали 312 пацієнтів, які були прооперовані за методикою степлерної гемороїдектомії. Чоловіків було 144 (46,2 \%), жінок - 168 (53,8 \%). Вік хворих коливався від 18 до 64 років; 262 пацієнти були працездатного віку. Усі хворі прооперовані з приводу гемороїдальної хвороби; у 117 (37,5 \%) пацієнтів була III стадія, у 195 (62,5 \%) з IV стадія захворювання. У всіх хворих діагностовано комбіновану форму геморою.

Групу порівняння склали 184 пацієнти контрольної групи, в яких було діагностовано геморой

III i IV стадій. Цим пацієнтам була виконана класична гемороїдектомія за Мілліганом-Морганом. Чоловіків було 82 (44,6 \%), жінок - 102 (55,4 \%), вік хворих коливався від 18 до 72 років. У 116 (63,1 \%) хворих встановлено діагноз геморою III стадії, у 68 (36,9\%)IV стадії.

Усі пацієнти з основної та контрольної груп отримували у ранньому післяопераційному періоді аналгетики двічі на день та додатково за потребою.

Оцінку результатів лікування проводили в ранньому післяопераційному періоді за допомогою розробленої нами комп'ютерної програми "Ternotel-Vida". Больові відчуття оцінювали за допомогою візуальної аналогової шкали ВонгаБейкера (рис. 1).

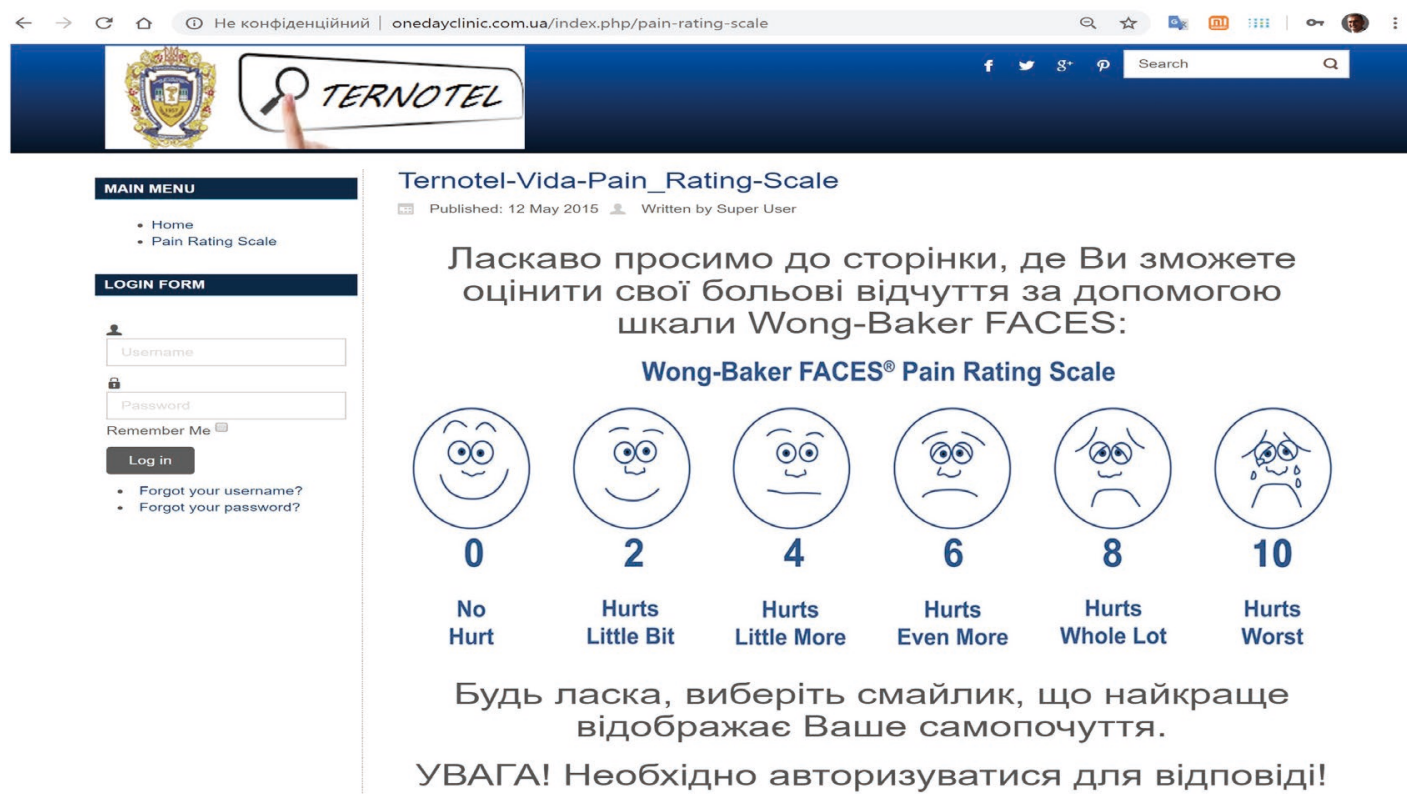

Рис. 1. Загальний вигляд програми "Ternotel-Vida” на сайті.

У рамках виконання фундаментальних та прикладних досліджень, що фінансуються за рахунок коштів державного бюджету, № 2301020 «Розробка спеціалізованого медичного обладнання і лікувально-реабілітаційних методик для надання телемедичної (дистанційної) допомоги пацієнтам із травмами та захворюваннями опорно-рухового апарату» авторами розроблена спеціалізована програма для оцінки болю “Ternotel-Vida”, яку пацієнти могли використовувати на своїх смартфонах або комп'ютерах. Тестування програми було проведено при веденні пацієнтів із пошкодженням колінних суглобів, які страждали від болю, під час телемедичної реабілітації. Це дозволило виявити деякі потенційні програмні проблеми, провести зміни для вдосконалення програми та зробити її інтерфейс зручним і зрозумілим для пацієн- тів. У процесі використання стало зрозуміло, що програму можна також використовувати при оцінці болю в пацієнтів із захворюваннями різної етіології, тривалості тощо. Ми використали вказану розроблену нами програму при оцінці болю у пацієнтів, які перенесли гемороїдектомію, проведену з використанням різних методик.

Усі пацієнти обох груп були навчені працювати з програмою ще під час перебування в стаціонарі. Їм було запропоновано щоденно, тричі на день, оцінювати біль за допомогою розробленої авторами програми "Ternotel-Vida" з використанням візуальної аналогової шкали Вонга-Бейкера. Пацієнтам було рекомендовано оцінювати свій біль приблизно в один і той самий час щодня до прийому аналгетиків (зранку, в обід та ввечері). На смартфоні або комп'ютері пацієнти відмічали смайлики 
Огляди літератури, оригінальні дослідження, погляд на проблему, випадок з практики, короткі повідомлення з цифрами, де оцінка 0 означала повну відсутність болю, а 10-максимальний біль, який переніс пацієнт у житті. При застосуванні розробленої нами програми усі дані передавалися на сервер та зберігалися там у зашифрованому, захищеному паролем вигляді. Доступ до даних мали лише дослідники та лікуючі лікарі цілодобово через адміністративний вхід, захищений індивідуальним паролем. При значному зростанні рівня болю в пацієнта лікуючий лікар отримував повідомлення про це на персональний телефон та мав можливість зв'язатися з пацієнтом.

Результати й обговорення. Середній вік пацієнтів контрольної групи склав $(54,17 \pm 1,1)$ років, основної групи - $(51,68 \pm 0,9)$ років, достовірних відмінностей між групами за віковими показниками не було. Проводився моніторинг пацієнтів в термін до 15 днів після операції. Тривалість операції в групі пацієнтів, яким виконували степлерну гемороїдектомію, склала (14ะ3) хв, а при відкритій гемороїд-

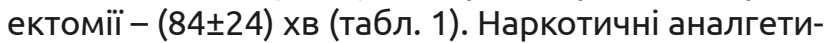

ки використовували лише в групі хворих після відкритої гемороїдектомії - в середньому 2 дози за вимогою пацієнта. Рівень болю за візуальною аналоговою шкалою Вонга-Бейкера в післяопераційному періоді на першу добу в контрольній групі був значно вищий, і склав, у середньому, 8 балів, порівняно з основною групою, де цей показник дорівнював 5 балів. До кінця першого тижня рівень болю рівномірно зменшувався в обох групах, проте кращі показники відмічалися в пацієнтів основної групи. Пацієнти контрольної групи перебували в стаціонарі в середньому $(7,2 \pm 1,0)$ днів після операції, що значно перевищує показник основної групи - $(2,7 \pm 1,1)$ днів. Це було обумовлено побоюваннями пацієнтів з контрольної групи щодо можливості повноцінного знеболювання в домашніх умовах. На 15-ту добу пацієнти основної групи не відчували болю в післяопераційній ділянці. У пацієнтів контрольної групи больові відчуття зберігалися після двох тижнів.

Таблиця 1. Результати порівняльного дослідження пацієнтів після степлерної гемороїдектомії та гемороїдектомії за Мілліганом-Морганом протягом 15 днів після операції

\begin{tabular}{|l|c|c|}
\hline \multicolumn{1}{|c|}{ Показник } & $\begin{array}{c}\text { Контрольна група, } \\
\mathrm{n}=188\end{array}$ & $\begin{array}{c}\text { Основна група, } \\
\mathrm{n}=312\end{array}$ \\
\hline Середній вік, роки & $54,17 \pm 1,1$ & $144(46,2 \%)$ \\
\hline Чоловіки & $82(44,6 \%)$ & $168(53,8 \%)$ \\
\hline Жінки & $102(55,4 \%)$ & $217(69,6 \%)$ \\
\hline Геморой III стадії & $116(63,1 \%)$ & $22 \pm 5$ \\
\hline Геморой IV стадії & $68(36,9 \%)$ & $5 \pm 2$ \\
\hline Тривалість операції, хв & $84 \pm 24$ & $4 \pm 1$ \\
\hline Оцінка болю на I добу, бали & $8 \pm 2$ & $4 \pm 1$ \\
\hline Оцінка болю на II добу, бали & $7 \pm 1$ & $3 \pm 1$ \\
\hline Оцінка болю на III добу бали & $6 \pm 1$ & $2 \pm 1$ \\
\hline Оцінка болю на V добу бали & $5 \pm 1$ & $1 \pm 1$ \\
\hline Оцінка болю на VII добу, бали & $5 \pm 1$ & 0 \\
\hline Оцінка болю на IX добу, бали & $3 \pm 1$ & - \\
\hline Оцінка болю на XV добу, бали & $2 \pm 1$ & $2,3 \pm 0,7$ \\
\hline Наркотичні аналгетики, днів & $2 \pm 1$ & \\
\hline Перебування в стаціонарі після операції, & $7,2 \pm 1,0$ & \\
\hline днів & & \\
\hline
\end{tabular}

Необхідно зазначити, що тривале перебування пацієнтів в умовах стаціонару також негативно впливає на суб'єктивну оцінку больового синдрому. Так, пацієнти контрольної групи, які перебували у відділенні 6-8 днів, після виписування відчу-

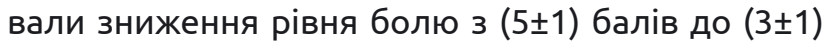
балів, тоді як пацієнти з основної групи на 9-у добу відчували лише незначний дискомфорт та відмовлялися від анальгетиків.

Оцінка болю, як відомо, є винятково суб'єктивним фактором, тому використання спеціалізованої комп'ютерної програми дозволяє ліквідувати емоційну складову та реальніше оцінити рівень болю у післяопераційному періоді. Усі пацієнти з обох груп зазначали, що використання розробленої нами програми в домашніх умовах давало їм відчуття контакту з хірургом та постійного перебування під контролем лікуючого лікаря. Це заспокоювало пацієнтів, вони були впевнені, що їхній лікар завжди зможе вчасно відреагувати на можливе посилення болю чи розвиток ускладнень.

На нашу думку, застосування вказаної інноваційної технології мобільного здоров'я для телемедичної оцінки післяопераційного болю дозволить зменшити навантаження на медичний персонал за рахунок зменшення кількості відвідувань клініки 
Огляди літератури, оригінальні дослідження, поглядн на пацієнтами у післяопераційному періоді та запитів щодо невідкладної допомоги. Ця інноваційна технологія сприятиме заохоченню пацієнтів самостійно керувати оцінкою своїх больових відчуттів за допомогою спеціалізованої програми під телемедичним контролем свого лікаря. У майбутньому перспективним $€$ використання алгоритмів штучного інтелекту для прогнозування поведінки пацієнтів, які схильні перебільшувати свій біль, або в яких він надто залежить від емоційної складової. Для таких пацієнтів потрібно створити алгоритми прийняття рішень, що покращить догляд за ними, зменшить їхні страждання від післяопераційного болю.

Висновки. 1. Степлерна гемороїдектомія $\epsilon$ надійною альтернативою гемороїдектомії за Мілліганом-Морганом і дозволяє зменшити рівень болю в післяопераційному періоді та скоротити період непрацездатності пацієнтів.

2. Використання спеціалізованої комп'ютерної програми дозволяє ліквідувати емоційну складову та реальніше оцінити рівень болю у післяопераційному періоді.

\section{ЛІТЕРАТУРА}

1. Simillis C. Systematic review and network metaanalysis comparing clinical outcomes and effectiveness of surgical treatments for haemorrhoids / C. Simillis, S. N. Thoukididou, A. A. Slesser // BJS. - 2015. - No. 102. P. 1603-1618.

2. Trompetto M. Evaluation and management of hemorrhoids: Italian society of colorectal surgery (SICCR) consensus statement / M. Trompetto, G. Clerico, G. F. Cocorullo // Tech. Coloproctol. - 2015. - No. 19 (10). - P. 567-575.

3. Rorvik H. D. Hemorrhoidal disease symptom score and short health scale HD: New tools to evaluate symptoms and health-related uality of life in hemorrhoidal disease / H. D. Rorvik, K. Styr, L. Ilum // Dis. Colon Rectum. 2019. - No. 62. - P. 333-342.

4. Shaikh A. R. An evaluation of Milligan-Morgan and Ferguson procedures for haemorrhoidectomy at Liaquat University Hospital Jamshoro, Hyderabad, Pakistan / A. R. Shaikh, A. G. Dalwani, N. Soomro // Pak. J. Med. Sci. 2013. - No. 29. - P. 122-127.

\section{REFERENCES}

1. Simillis, C., Thoukididou, S.N., \& Slesser, A.A. (2015). Systematic review and network meta-analysis comparing clinical outcomes and effectiveness of surgical treatments for haemorrhoids. BJS, 102, 1603-1618.

2. Trompetto, M., Clerico, G., \& Cocorullo, G.F. (2015). Evaluation and management of hemorrhoids: Italian society of colorectal surgery (SICCR) consensus statement. Tech. Coloproctol., 19(10), 567-575.

3. Rorvik, H.D., Styr, K., \& Ilum, L. (2019). Hemorrhoidal disease symptom score and short health scale HD: New tools to evaluate symptoms and health-related uality of life in hemorrhoidal disease. Dis. Colon Rectum., 62, 333-342.

4. Shaikh, A.R., Dalwani, A.G., \& Soomro, N. (2013). An evaluation of Milligan-Morgan and Ferguson procedures for haemorrhoidectomy at Liaquat University Hospital Jamshoro, Hyderabad, Pakistan. Pak. J. Med. Sci., 29, 122-127.

5. Prati, Andrea, Shan Caifeng, Wang, \& Kevin I-Kaic (2019). Sensors, vision and networks: From video surveil-

5. Prati Andrea Sensors, vision and networks: From video surveillance to activity recognition and health monitoring / Prati Andrea, Shan Caifeng Wang, Kevin I-Kaic // Journal of ambient intelligence and smart environments. 2019. - No. 11. - P. 5-22.

6. Tsvyakh A. Telerehabilitation of patients with injuries of the lower extremities / A. Tsvyakh, A. Hospodarskyy // Telemed. J. E. Health. - 2017. - No. 23. - P. 10111015. DOI: $10.1089 /$ tmj.2016.0267.

7. Sasidhar S. A real time control algorithm for a myoelectric glove for the rehabilitation of wrist and elbow of stroke patients / S. Sasidhar, S. K. Panda, J. Xu // 8th IEEE Int Conf on control and automation. - 2010. - P. 745-749.

8. Performance evaluation of sensing fabrics for monitoring physiological and biomechanical variables / S. Enzo Pasquale, A. Gemignani, R. Paradiso, N. Taccini // IEEE T. Inf. Technol. B. - 2005. - No. 9 (3). - P. 345-352.

9. Internet site: http://onedayclinic.com.ua/index. php/pain-rating-scale.

lance to activity recognition and health monitoring. Journal of Ambient Intelligence and Smart Environments, 11, 5-22.

6. Tsvyakh, A., \& Hospodarskyy, A. (2017). Telerehabilitation of patients with injuries of the lower extremities. Telemed. J. E. Health, 23, 1011-1015. doi: 10.1089/ tmj.2016.0267.

7. Sasidhar, S., Panda, S.K., \& Xu, J. (2010). A real time control algorithm for a myoelectric glove for the rehabilitation of wrist and elbow of stroke patients. 8th IEEE Int. Conf. on Control and Automation, 745-749.

8. Enzo Pasquale, S., Gemignani, A., Paradiso, R., \& Taccini, N. (2005). Performance evaluation of sensing fabrics for monitoring physiological and biomechanical variables. IEEE T Inf. Technol. B., 9 (3), 345-352.

9. Internet site: http://onedayclinic.com.ua/index. php/pain-rating-scale. 
Огляди літератури, оригінальні дослідження, погляд на проблему, випадок з практики, короткі повідомлення

\section{ИННОВАЦИОННЫЕ МЕТОДЫ ТЕЛЕМЕДИЦИНСКОГО МОНИТОРИНГА БОЛЕВОГО СИНДРОМА ПОСЛЕ ГЕМОРРОИДЭКТОМИИ}

\section{○И. Я. Дзюбановский, А. И. Цвях, А. Я. Господарский, Р. С. Древницкий}

Тернопольский национальный медицинский университет имени И. Я. Горбачевского МОз Украины

РЕЗЮмЕ. Проведено сравнение методик геморроидэктомии по Милигану-Моргану и степлерной геморроидэктомии при хирургическом лечении геморроя III-IV стадий.

Материал и методы. 184 пациента, перенесших геморроидэктомию по Милигану-Моргану, и 312 пациентов после степлерной геморроидэктомии составили контрольную и основную группы. Был проведен анализ послеоперационного болевого синдрома с помощью специальной разработанной авторами программы.

Результаты. Уровень боли по визуальной аналоговой шкале Вонга-Бейкера в послеоперационном периоде в первые сутки в контрольной группе был значительно выше и составил, в среднем, 8 баллов, по сравнению с 5 баллами в основной группе. На 15-е сутки пациенты основной группы не испытывали боли в послеоперационной области. У пациентов контрольной группы болевые ощущения сохранялись после двух недель. Все пациенты обеих групп отмечали, что использование программы в домашних условиях давало им ощущение контакта с хирургом и постоянного контроля боли со стороны лечащего врача.

Выводы. Степлерная геморроидэктомия является надежной альтернативой геморроидэктомии по Милигану-Моргану и позволяет уменьшить уровень боли в послеоперационном периоде и сократить период нетрудоспособности пациентов. Использование специализированной компьютерной программы позволяет ликвидировать эмоциональную составляющую и реально оценить уровень боли в послеоперационном периоде.

КЛюЧЕВЫЕ СЛОВА: телемедицина; геморроидэктомия; оценка боли.

\section{INNOVATIVE METHODS FOR TELEMEDICINE MONITORING OF PAIN AFTER HEMORRHOIDECTOMY}

\section{OI. Ya. Dziubanovskyi, A. I. Tsvyakh, A. Ya. Hospodarskyi, R. S. Drevnitskyi I. Horbachevsky Ternopil National Medical University}

SUMMARY. We aimed to compare long-term outcomes in patients undergoing circular stapled hemorrhoidectomy to those who had Milligan-Morgan hemorrhoidectomy.

Material and Methods. 184 patients who underwent Milligan-Morgan hemorrhoidectomy and 312 patients who underwent circular stapled hemorrhoidectomy were reviewed. Long-term follow-up was assessed by using software and telemedicine pain monitoring.

Results. The pain level on the first day in the control group was significantly higher - averaged 8 points compared to 5 points in the main group. On the 15th day, patients in the main group did not fill any pain in the postoperative area. Patients from the control group fill pain after two weeks. All patients in both groups noted that using the software at home gave them a sense of contact with the surgeon.

Conclusions. Compared with Milligan-Morgan hemorrhoidectomy, stapled hemorrhoidectomy resulted in less postoperative pain, shorter operating time, and shorter hospital stay. Using a specialized software allows to eliminate the emotional component and to evaluate the pain level in the postoperative period more realistically.

KEY WORDS: telemedicine; hemorrhoidectomy; pain monitoring. 